症例

脾内へ伸展し脾襄胞をも合併した膵貯留性囊胞の 1 例

岡山大学第 2 外科

松本英男平井隆二植村忠宏山野寿久

村上正和太田徹哉 土井原博義清水信義

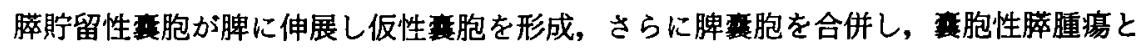
の鑑別を要した症例を経験したので報告する。

症例は 47 歳の男性で, 慢性膆炎の経過中に囊胞性膵腫瘍を疑われ当科紹介となった。 腹部 US, CT, MRI で脺尾部に $13 \times 12 \mathrm{~cm}$ の壁は一部肥厚し, 内部に隔壁様の充実性部

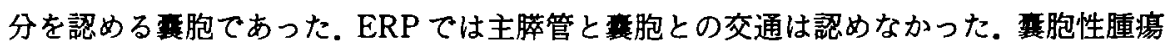
を否定できず，脺体尾部・脾切除術を施行した。

組織学的には,膵と噒接した塞胞壁に膵管上皮が残存しており貯留亳胞と診断された. しかし, 脾側の宾胞壁は脾実質で構成され, 被膜は認めなかった. 膵貯留壤胞が脾内へ 仮性毫胞を形成, さらに圧排による血行不全のため脾梗塞をおこし, この後に脾囊胞が 形成されたと考えられた.

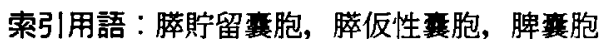

\section{はじめに}

近年, 画像診断の発達とともに脺の塞胞性疾患の発 見は容易になり，鑑別診断技術は飛躍的に向上してい ると思われる ${ }^{122)}$. しかしながら，臨床上の取り扱いに 関しては，質的診断，治療方針に苦慮する場合も少な くない.脾内へ穿破し仮性暴胞を形成し，さらに脾辜 胞を合併し，襄胞性脺腫瘍との鑑別に苦虑した膵の貯 留性业胞を経験したので, 文献的考察を含めて報告す る.

症例：47歳, 男性.

症例

主訴：上腹部不快感。

既往歴：平成元年より慢性膵炎.

家族歴：特記すべきことなし.

現病歴：平成元年の急性膆炎発症時より再発を繰り 返し, 慢性脺炎へ移行し, 近医にて治療を受けていた。 平成 7 年 10 月に急性增悪をきたし，入院治療を受けた さい, 膵尾部の董胞と血中 CA19.9の上昇を認めたた め当科紹介となった。

アルコール摄取：ビール 2 本/日

現症：身長 $167 \mathrm{~cm}$, 体重 $57 \mathrm{~kg}$ 。負血・黄疸を認めず，

1998年 3 月 4 日受付 1998 年 6 月 12 日採用
表在リンパ節を触知せず. 胸部理学所見に異常を認め なかった．腹部は平坦で軟．左上腹部に軽度の圧痛は 認めるものの, 腫瘤は触知しなかった。

入院時検查所見 : 炎症所見等は認めないものの, 血 中アミラーゼは $533 \mathrm{IU} / l$, 血中 CA19-9は $260 \mathrm{U} / \mathrm{ml}$ と上 昇していた (表 1).

腹部超音波検査所見：膵管は董胞状に㹡張し，膵尾 部に $13 \times 12 \mathrm{~cm}$ の内空が均一な low echoic lesion を認

表 1 Laboratory date on admission

\begin{tabular}{lc|lr}
\hline WBC & $4,900 / \mu l$ & s-AMY & $\underline{533} \mathrm{IU} / l$ \\
$\mathrm{RBC}$ & $3.38 \times 10^{6} / \mu \mathrm{l}$ & $\mathrm{Na}$ & $139 \mathrm{mmol} / l$ \\
$\mathrm{Hgb}$ & $11.0 \mathrm{~g} / \mathrm{dl}$ & $\mathrm{K}$ & $4.1 \mathrm{mmol} / l$ \\
$\mathrm{Hct}$ & $32.5 \%$ & $\mathrm{Cl}$ & $103 \mathrm{mmol} / l$ \\
$\mathrm{Plt}$ & $341 \times 10^{3} / \mu \mathrm{l}$ & $\mathrm{Ca}$ & $8.5 \mathrm{mg} / \mathrm{dl}$ \\
T.P. & $6.65 \mathrm{~g} / \mathrm{dl}$ & $\mathrm{Crea}$ & $0.46 \mathrm{mg} / \mathrm{dl}$ \\
$\mathrm{Alb}$ & $3.63 \mathrm{~g} / \mathrm{dl}$ & $\mathrm{BUN}$ & $8.5 \mathrm{mg} / \mathrm{dl}$ \\
T. Bil & $0.37 \mathrm{mg} / \mathrm{dl}$ & $\mathrm{CRP}$ & $0 \mathrm{mg} / \mathrm{dl}$ \\
GOT & $17 \mathrm{IU} / l$ & CEA & $3.26 \mathrm{ng} / \mathrm{ml}$ \\
GPT & $10 \mathrm{IU} / l$ & Span-1 & $\underline{68.9} \mathrm{U} / \mathrm{ml}$ \\
ALP & $83 \mathrm{IU} / l$ & DUPAN-II & $\underline{156} \mathrm{U} / \mathrm{ml}$ \\
LAP & $54 \mathrm{IU} / l$ & CAl9-9 & $\underline{260} \mathrm{U} / \mathrm{ml}$ \\
$\gamma \cdot$ GTP & $28 \mathrm{IU} / l$ & & \\
CHE & $129 \mathrm{IU} / l$ & & \\
LDH & $245 \mathrm{IU} / l$ & & \\
\hline
\end{tabular}


めた，膵管との交通は明らかではなかった。䡒胞壁は 一部肥厚し, 隔壁様に内腔に隆起していた(図 $\mathbf{l a}, \mathbf{b})$. 腹部 CT：造影 CT にて，膵の萎縮と膵管の著明な 拡張を認めた. 膵尾部には $13 \times 12 \mathrm{~cm}$ の变胞を認めた。 咅胞壁は一部肥厚し，内腔に突出する隆起を有し隔壁 様に描出された。糞胞内容はほほ均一に low density を示した。脾は強く王排されており脾内にも集胞を認 めた（図 2, 図3d).

腹部 MRI：㳦胞内容は T1強調像, T2強調像で共に high intensity を示した. 膵尾部に $13 \times 12 \mathrm{~cm} の$ 亯胞を 認めた。CT と同様に㘊胞壁は肥厚しその内部に隔壁 様の充実性部分を認めた（図 3a, b, c).

ERP：主膵管の变胞状拡張と一次分枝の拡張を認 めたが,膵尾部の菩胞との交通は描出されなかった(図 1c, d).

血管造影：脾動脈造影では，脾動脈は圧排・伸展さ れていたが，旁胞壁に新生血管は認めず，壁の濃染も 認めなかった，脾静脈は描出されず，左胃静脈などへ の側副血行が発達していた（図4)。

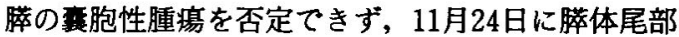

切除を施行した。

手術時所見：膵は線維化・菲薄化が著しかった。襄 胞壁は厚く，周囲組織と瘄着していたが浸潤はなかっ た. 血管造影で認めた側副血行路を処理した後に，脾 動静脈を処理, 体部で切除を行った。脾静脈は開存し ており圧迫による血流の途絶と考えられた。

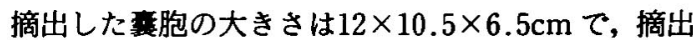
後の膵管造影では菨胞との交通は認めなかった（図 5 a, c). 咅胞内容は, $600 \mathrm{ml}$ の濃緑色の液体で, amylase $106,500 \mathrm{IU} / l$, CEA $28.1 \mathrm{ng} / \mathrm{ml}$, CA19-9 259,800U $/ \mathrm{ml}$ であり, 細菌培養は陰性であった。

摘出標本の冠状断では，䟺胞内に腫瘍性隆起は認め ず，単房性であった。棌胞内壁は脺頭側は黄白色で平 滑だが，脾側は濃褐色の苔状物におおわれており，こ の境界部の頭側は脾実質が隔壁様に内腔に突出してい た.この隔壁様突出部より脾側の塞胞壁は脾が圧排・ 伸展された状態で構成しており, 脾内にも最大 $2 \mathrm{~cm} の$ 塞胞を 3 個認めた（図 $5 b$, d).

病理組織所見：膵実質は線維化が著しく，膵頭側の 䧶胞壁は膵実質が構成していた。この部の雍胞上皮は，

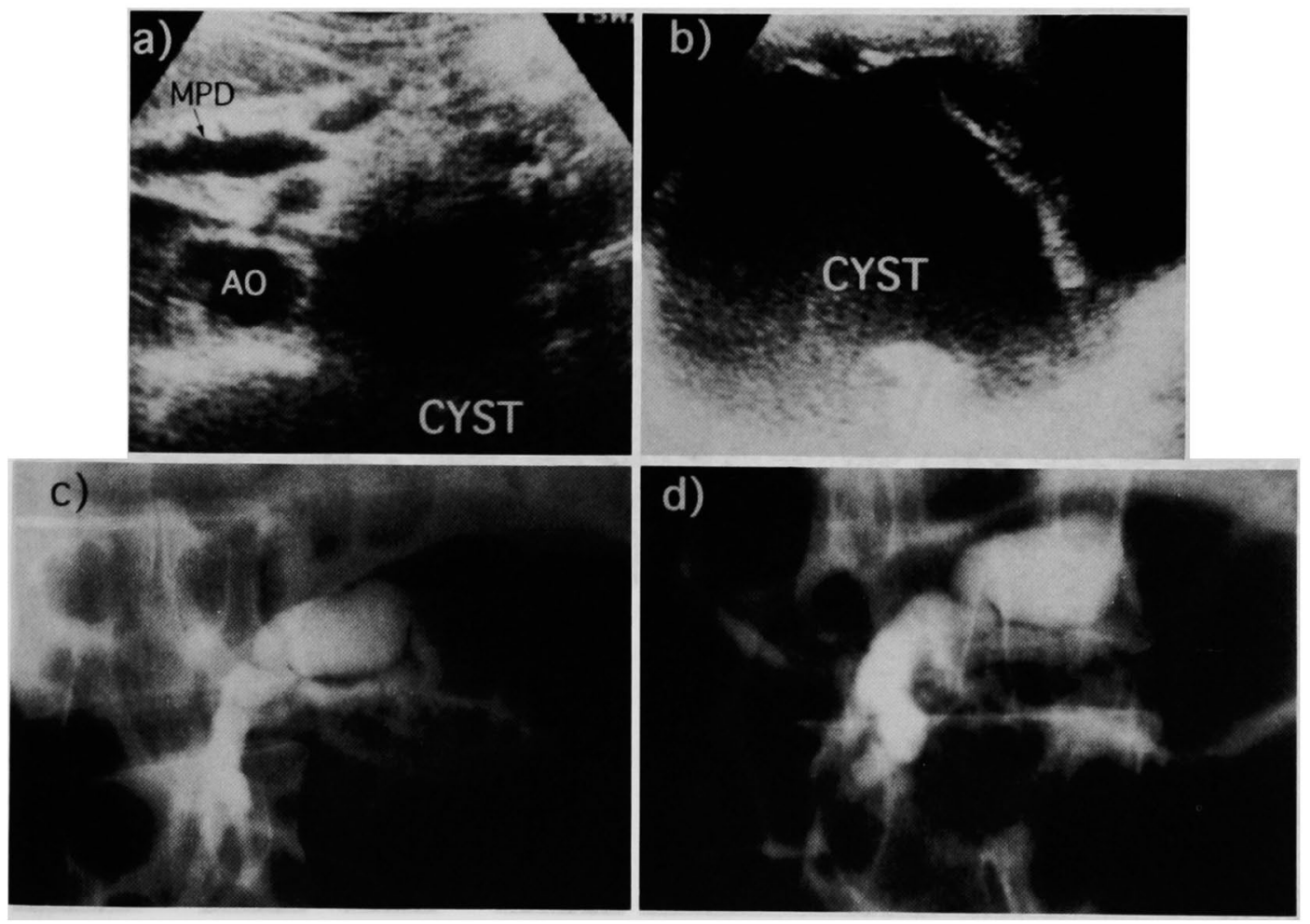

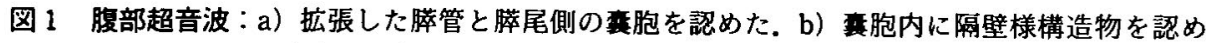
た. c)d）ERPでは堡胞との交通は諗めなかった。 

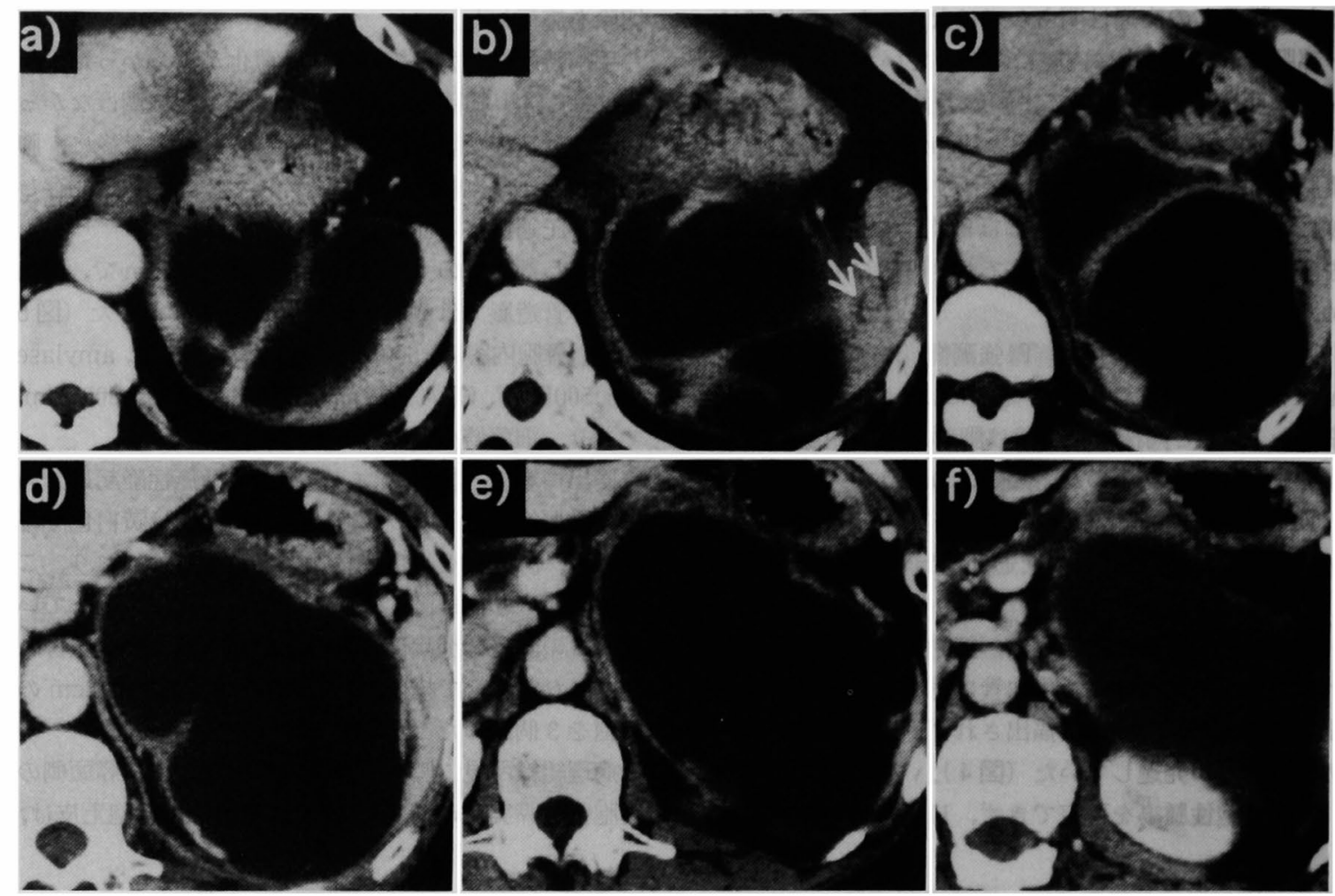

図 2 腹部 CT 率胞壁は一部肥厚し，内腔に突出する隆起を有し隔壁様に描出された。匠排された

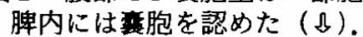
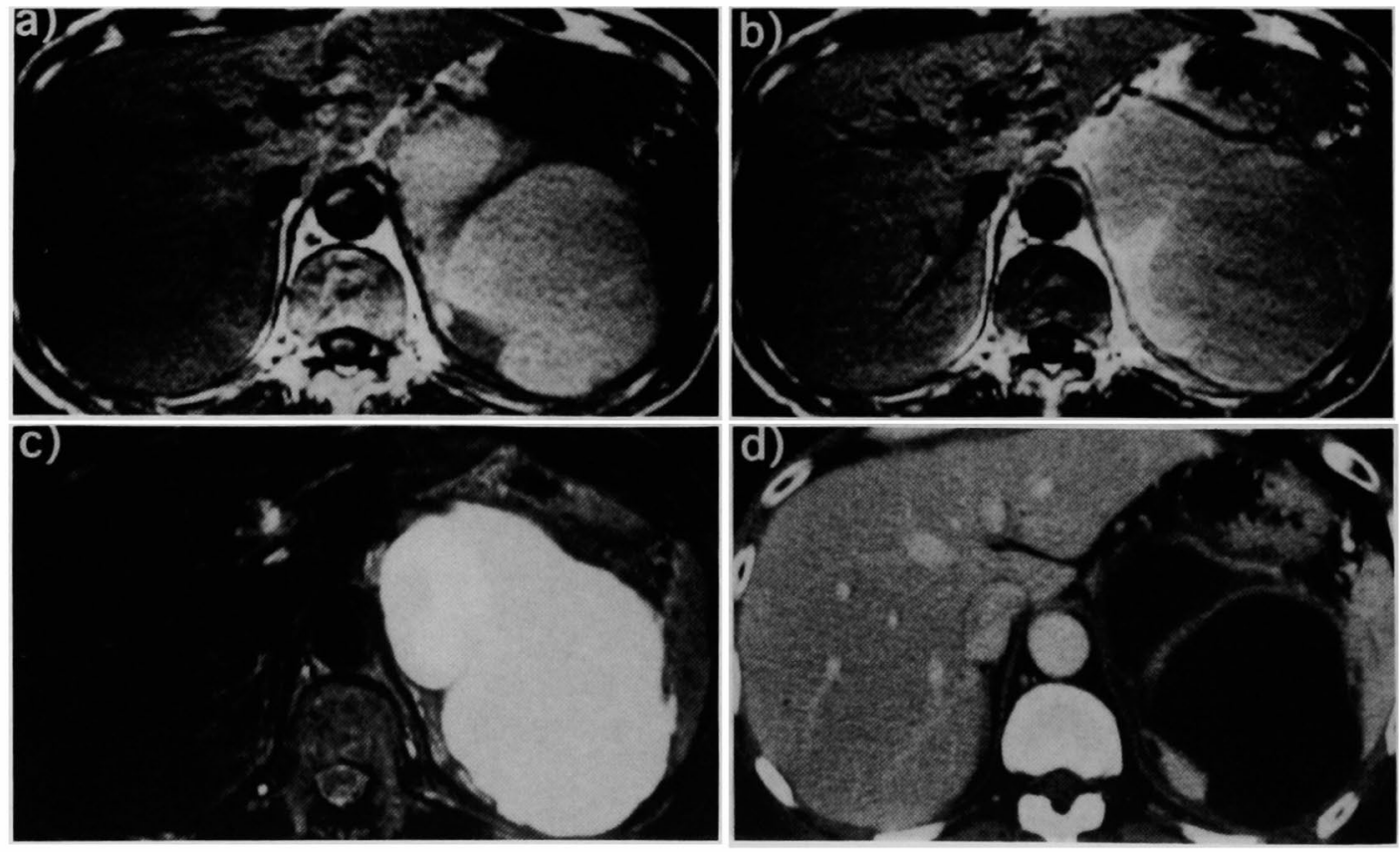

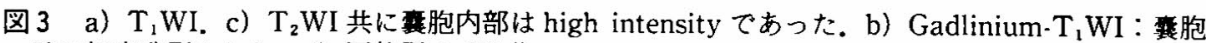
壁は軽度造影された. d) 同位置のCT 像. 

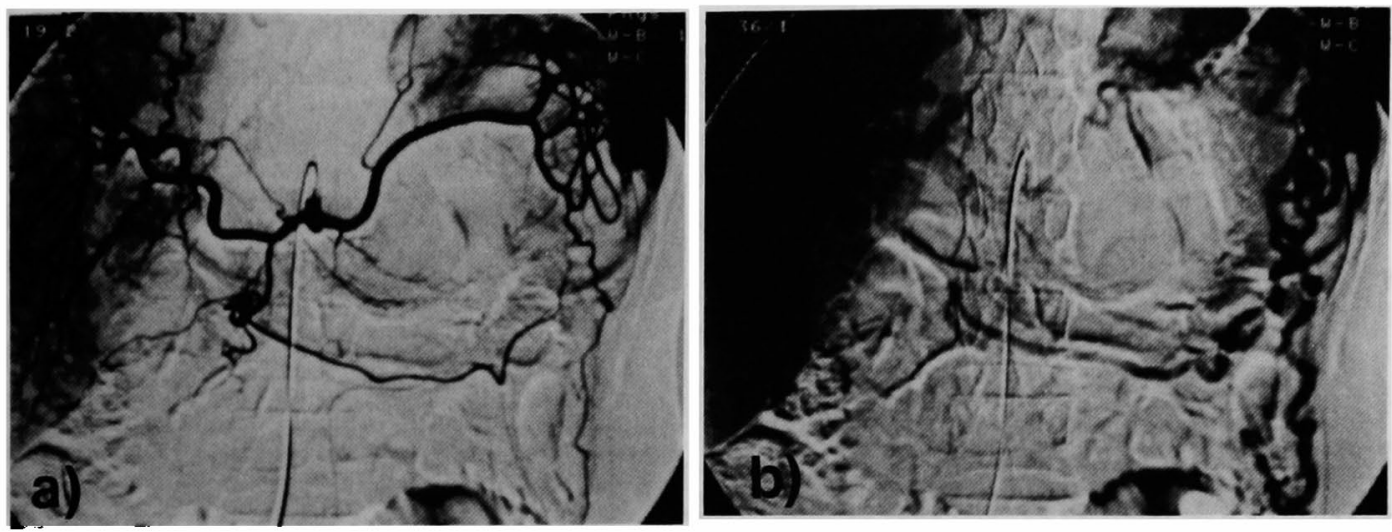

図 4 a) 腹腔動脈造影：異胞壁に新生血管は認めず，壁の濃染も認めなかった，b）脾静脈は描出 されず，左胃静脈などへの側副血行が発達していた。
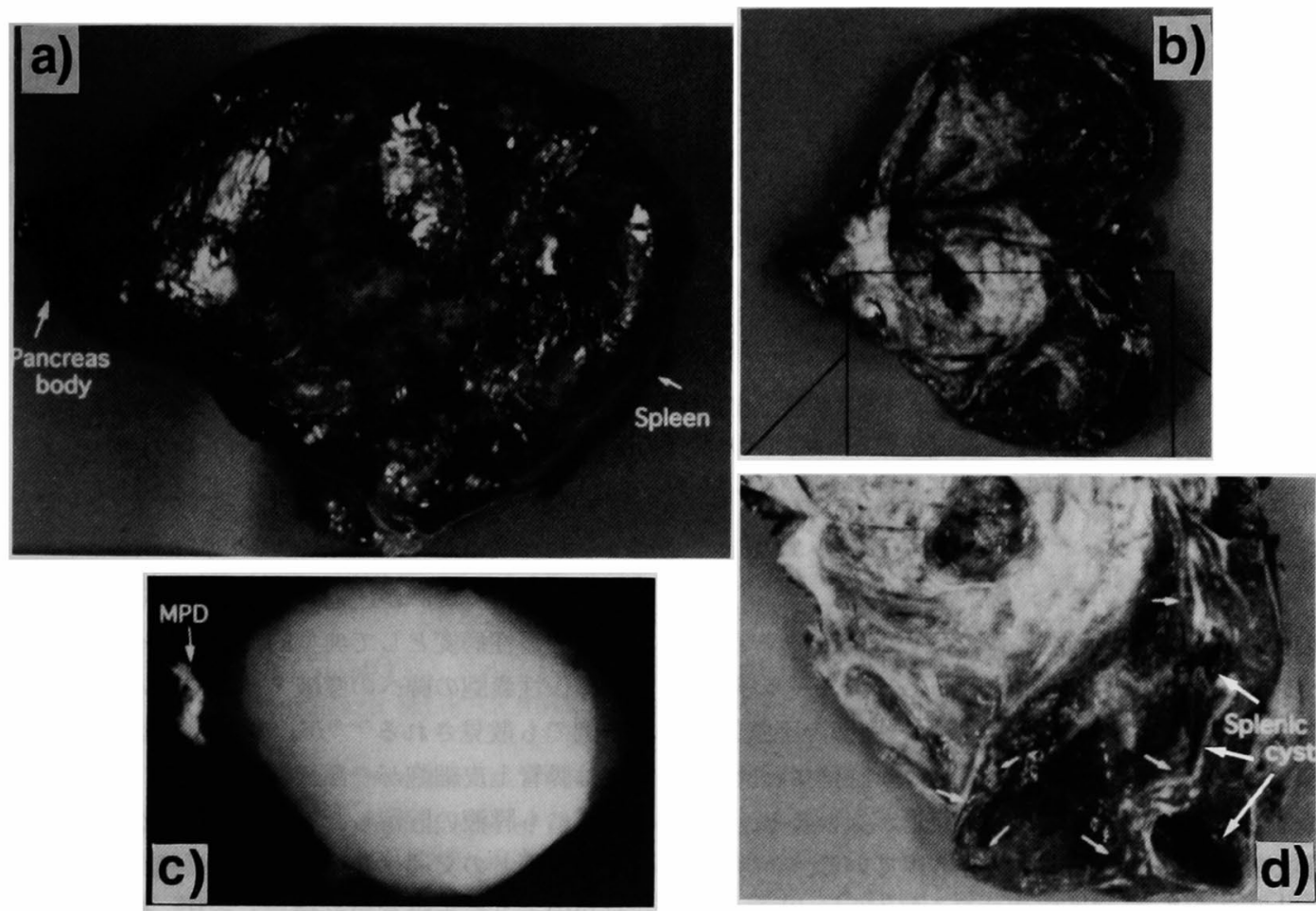

図 5 a) 摘出標本. c) 摘出標本萃管造影. 膵管と翼胞の交通は認めなかった. b) 冠状断面. d) 冠 状断面の拡大：（ß）脾と襄胞との境界部を示す.（†）脾内の衰胞.

一部に脺管上皮細胞を残すのみでほほ脱落しており， 主膵管と近接し, 周囲の膵実質内にも拡張した膵管が 存在し, 脺分泌液の貯留が認められた (図 6a, c).こ のことょり，貯留亯胞が起因したものであると考えら れた. 脾側の軎胞壁は菲薄化した脾実質が構成してお り(図 6b)，脾顀胞も散見された。
脾内の垔胞周囲の脾実質には脾門部の血流障害から と推測される梗塞像が散見され，脾内の襄胞も梗塞に より形成されたと考えられた(図6d)。すなわち，慢性 膵炎に合併した貯留囊胞が脾内に穿破し仮性亯胞を形 成し,さらに脾門部の血流不全により脾亯胞をも合併 したと考えた。 


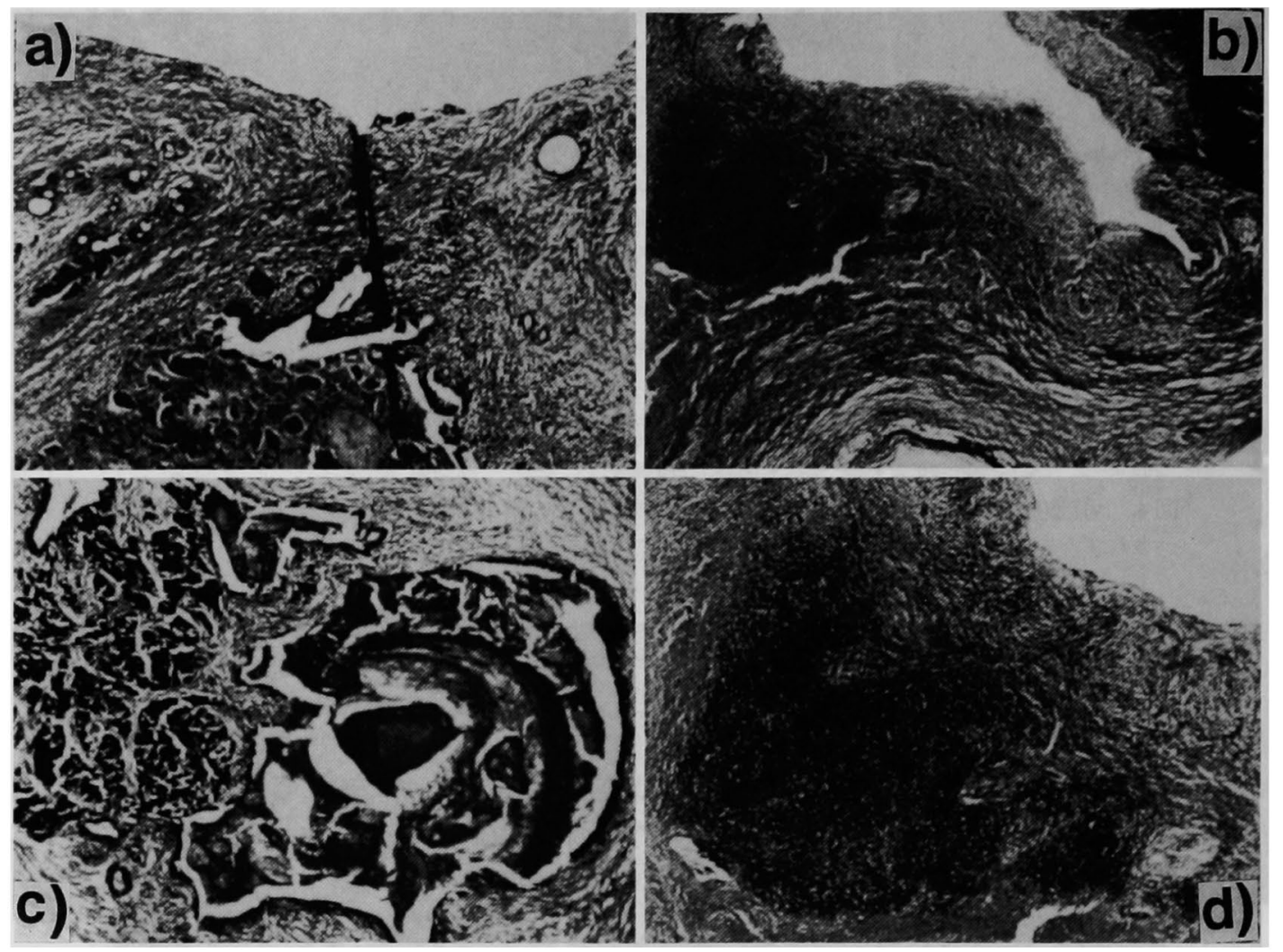

图 6 a）膵側の暴胞壁には一部に膵管上皮細胞を認めた。 c) 周囲の膵実質内にも拡張した膀管が

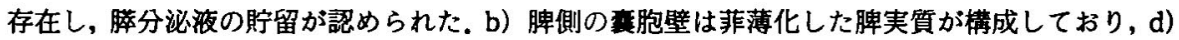
脾内には脾毫胞とともに梗塞巣を認めた。

\section{考察}

膵の腫瘍性亳胞の特徴として, Warshaw ${ }^{3) ゃ A n-~}$ drew ら や外傷などの既往がないこと.画像上趸胞壁の不整像, 隔壁様構造や充実性部分があること，毫胞壁に石灰化 を認めるもの. ERCP で膵管との交通がないこと，血 管造影で血流が豊富なことなどをあげている。

また中迫ら つ襄胞内腔に隆起または隔壁の両方またはいずれか一 方を指摘できれば腫瘍性病変の可能性が極めて高いと 指摘している。

本症例は，美胞が大きく，膵管との交通を認めず， 造影 CT でエンハンスメントされる輬胞壁の肥厚や隔

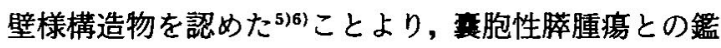
別に難渋し，膵体尾部切除と脾摘出を行った。しかし 結果的に考えれば，基礎疾患に慢性脺炎があり， Dynamic CT や血管造影で新生血管の増生は認め
ず5)6)，また脾静脈が圧迫によって途絶していたことな どは腫瘍性病変として典型的ではなかった。

膵仮性襄胞の脾への穿破・伸展については, 本邦報

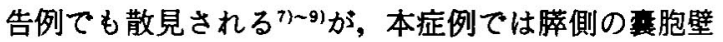
には膵管上皮細胞が一部残存しており，菨胞周囲の膵 実質にも脺液の貯留した拡張した膵管を認めた。衰胞 と主膵管との交通はないものの，咅胞内と交通があっ たかのように主膵管が近接しており，初期には交通が あり，夜体が貯留し莫胞化したものと考えられた。 の後も繰り返す膵炎のため, 膵頭側の膵管が途絶し, 貯留莗胞が破綻して脾内に穿破し，仮性垩胞を形成し

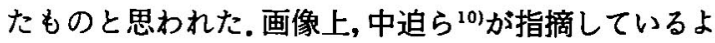
うに，堡胞壁は繰り返す炎症のため分厚く肥厚し，内 腔へ突出した隔壁様構造物は仮性趸胞の壁を構成する 脾実質であったことが鑑別に迷う結果となった。

脾索胞については，脾内に梗塞巣が認められること から，脾門部が仮性隻胞の形成による圧排のため萁胞 
が形成されたものと類推された. Boliver ら"1は脾内 黄胞の発生機序を，(1)仮性烡胞が直接脾内に穿破，(2) 膵炎による膵酵素の脾血管および脾実質への直接作 用，(3)異所性脾内組織の咅胞形成，(4)膵炎による脾動 静脈の血栓形成のために生じた脾梗塞あるいは血腫の 融解と述べており，本症例では脾門部の仮性哓胞は(1) の機序, 脾内の多発辜胞は(4)の機序が考えられた.

萁胞内容液について，CEA·CA19-9が高值のものは 蓄胞腺腫や赛胞腺癌といった悪性の咅胞性疾患に頻度

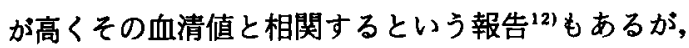
本症例ではむしろ慗胞内容のアミラーゼ值が高值 ${ }^{13)}$ あり仮性基胞を含めた炎症性裏胞の性格を表していた のであろう。

超音波誘導下の経皮的ドレナージも考慮したが，腫 瘍性病変の場合の播種 ${ }^{3)}$ という可能性も考えて細胞診 をふくめて穿刺は行わなかった．結果的には空腸や胃 との吻合で十分であったが, biopsyや frozen section による診断も腫煌性病変との鑑別は難しいとされてお $\eta^{335)}$ 切除は妥当であったと考えている.

\section{文献}

1) 黒田 慧, 杉山政則：膵董胞性病変·疾患の臨床病 理学的課題. 消外 $15: 427-438,1992$

2）中迫利明, 羽生富士夫, 今泉俊秀他：膵辜胞性疾患 の鎹別診断. 胆と脺 $11: 53-60,1990$

3) Warshaw AL, Compton CC, Lewandrowski K, et al: Cystic tumors of the pancreas. New clinical, radiologic and pathologic observation in 67 patients. Ann Surg $212: 432-445,1990$

4) Warshaw AL, Rutledqe PL: Cystic tumors mistaken for pancreatic pseudocysts. Ann Surg 205 : 393-398, 1987

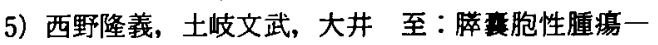
1. 消外 15:1913-1921，1992

6）張 正和，土岐文武，中迫利明他：脺重胞性腫瘍 (2)一いわゆる粘液産生脺腫場一. 消外 $15: 2183$ $-2193,1992$

7）豊田蝪彦, 菅沢 章, 万木英一他：脾内に穿通し,

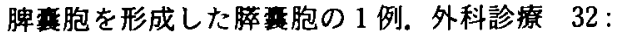
$1301-1304,1990$

8）石部良平, 田中紜輝，山田和彦他：脾内に波及した 脺仮性基胞の 2 手術治験例。日消外会誌 25 ： $2421-2425,1992$

9）佐藤公司, 村田貞史, 岡 敬三他：脾内に進展した と考えられる膵仮性衰胞の1例. 日臨外医会誌 $55: 2655-2661,1994$

10）中迫利明, 今泉俊秀, 原田信比古他：膵塞胞性疾患 の良悪性鑑別診断. 外科 $57: 760-766,1995$

11) Boliver JC, Lempke RE: Pancreatic pseudocyst of spleen. Ann Surg 179: 73-78, 1974

12) Tatuta $M$, Ishii $H$, Ichii $M$, et al : Values of Carcinoembryonic antigen, Elastase 1 , and Carbohydrate antigen determinant in aspirted pancreatic cystic fluid in the diagnosis of cysts of the pancreas. Cancer 57:1836-1839, 1986

13）山中桓夫, 上野規男, 木村 健：穿刺による膵要胞 性疾患の動態診断. 胃と腸 $25: 189-196,1990$

\title{
A CASE OF RETENSION CYST OF THE PANCREAS FORMING A PSEUDOCYST IN THE SPLEEN WITH SPLENIC CYST
}

\author{
Hideo MATSUMOTO, Ryuji HIRAI, Tadahiro UEMURA, Kotohisa YAMANO, \\ Masakazu MURAKAMI, Tetsuya OHTA, Hiroyoshi DOIHARA \\ and Nobuyoshi SHIMIZU \\ Second Department of Surgery, Okayama University, School of Medicine
}

We report a case of retension cyst of the pancreas extended to the spleen, and formed a pseudocyst there with splenic cyst. It was difficult to distinguish benign cyst from malignant cystic tumor; cystic adenoma or adenocarcinoma. A 47-year-old man was referred to the institute with a suspicion of pancreatic cystic tumor during the course of chronic pancreatitis. Abdominal urtrasonography, CT scan and magnetic resonance imaging revealed a cystic lesion on the pancreas tail, $13 \times 12 \mathrm{~cm}$ in size. The wall of the cyst was thickened partly, and there was a solid part which looked like septums. ERP revealed the dilated main duct without communication to the cyst. We diagnosed the case as probable cystic neoplasm of the pancreas and performed a distal pncreatectomy and a splenectomy.

Histologically, ductal epitheliums of the pancreas remained partly on the cystic wall of the pancreas side so that the cystic lesion was diagnosed as retention cyst of the pancreas. But the wall of the cyst was consist of the spelic cell without capsule of the spleen. Further more, cysts were recognized in the spleen.

It is etiologically concluded that the retension cyst of pancreas formed the pseudocyst in the spleen and then splenic infarction occurred due to compression by the pancreatic cyst, causing the splenic cysts. 